\title{
POLICY MEASURES FOR VIET NAM TOURISM IN RESPONSE TO IMPACTS OF COVID-19
}

\author{
Vu Chien Thang* \\ Research Management and International Cooperation, Institute for Tourism Development Research \\ 58 Kim Ma, Ba Dinh, Ha Noi, Vietnam
}

Received 27 April 2020

Revised 05 July 2020; Accepted 30 November 2020

\begin{abstract}
While the global community is taking urgent measures to overcome difficulties for production and businesses and ensure social security in response to the Covid-19 pandemic, Vietnam tourism industry needs to develop policy measures to minimize economic recession. Based on the research documents of international development organizations on developing policy measures for socio-economic recovery and case studies in Asian countries when the pandemic outbreaks in the region and the world, we propose policy measures to manage Vietnam destination as a national tourism destination. Given the impacts by Covid-19 pandemic, the policy measures addressed in this paper are divided into 3 groups: (1) support businesses to minimize economic losses in order to best promote the tourism business models in pandemic situations; (2) promote tourism stimulus programs and public-private partnerships; and (3) restructure tourism businesses and proper business management models for a new normal situation, in line with Sustainable Development Goals in the long term.

Keywords: policy measure, Vietnam tourism, pandemic, Covid-19.
\end{abstract}

\section{Introduction}

In mid-December 2019, a novel and infectious virus corona (COVID-19) struck Wuhan, the most populous city in central China. Similar to the severe acute respiratory syndrome (SARS) that emerged in 2003, COVID-19 is an airborne illness that is highly transmittable between humans. Immediately after the Chinese government shared information about the virus publicly in late January 2020, stricter preventive measures, such as community quarantines and temporary business closures, swept across Chinese cities. The local outbreak quickly developed into an emerging public health crisis to the extent that World Health Organization (WHO) soon declared it as an unprecedented global pandemic (WHO, 2020; Yang et al., 2020). According to World Tourism

Tel.: 84-988759957, Email: phaptanhnt@gmail.com
Organization: A United Nations Specialized Agency (UNWTO) (2020a), international tourism arrivals could fall by $20-30 \%$ in 2020 , which could be translated into a decline in international tourism receipts (exports) of between US\$300-450 billion, almost one third of the US\$ 1.5 trillion generated in 2019. The outbreaks of coronavirus threaten economic development and greatly harm the tourism industry. As tourism products own characters of intangibility, un-restorability, tourist services once produced failed to be sold are lost forever: an unsold hotel room is gone, an unsold table in a restaurant is also uncovered, a trip is not executed at a certain time means its value is partly lost as time does not stand still and is not scalable. This paper focuses on what considerable policy measures that governments can do to manage tourism destinations in response to impacts by Covid-19. 


\section{Literature review}

\subsection{Dealing with global pandemics and Covid-19}

Tourism is one of the most vulnerable sectors affected by epidemics. Take a look at the lessons from the Severe Acute Respiratory Syndrome epidemic caused by the SARS coronavirus (SARS-CoV) in 2003 that scared the world by its unprecedented danger and rapid spread. At that time, visual examinations at airports were quickly replaced by body temperature tests (by infrared scanners). However, this measure did not demonstrate high effectiveness. In SARS outbreak, more than 35 million international tourists had body temperature scans in Canada, China (including mainland and Hong Kong) and Singapore, but not any SARS case was detected. Therefore, it was argued that instead of investing in screening measures at airports to detect rare infectious diseases, it would rather invest in strengthening the capacity of screening and disease control at disease entry points of health systems (Wilder-Smith, 2006). The author also asserts that screening at departures is more effective in terms of preventing locals from traveling abroad but it is difficult to prevent sick travelers from trying to return home. Another research by Bell et al. showed that after WHO recommended departure censorship on 27 March 2003, not any new cases of SARS infection were detected among countries that had airport screenings. Aggregate data from China (including Hong Kong and Taiwan) showed that out of 1.8 million people who completed the health questionnaire on departure, only 1 case of SARS was suspected. Aggregate data from Canada, China and Singapore indicated that none of the SARS cases among more than 7 million people who had infrared scans at departures (Bell et al., 2004). Regarding policy solutions, many coordination among public and private organizations in communications and destination marketing to create psychological safety for tourists and boost domestic markets, stimulating tourism demand by such methods as discounts, cost savings, proper use of human resources and performance and capacity improvement. Governments also actively support tourism businesses to come up with initiatives to enhance public sanitation standards (Benjamin, 2007).

From March to date, a number of policy measures were taken by governments in order to reduce the impacts of the disease on the tourism sector. The objective of the government policies are to keep people in jobs, avoiding the worst with regard to layoffs, secure short term liquidity (such as ability to pay off its current liabilities with its current assets) and stabilize long term solvency (such as ability to pay for long-term debt in the long run) and by that prevent personal as well as company bankruptcies (International Association of Scientific Experts in Tourism, 2020). In general, most countries strengthen their policy measures on tax reduction; bank loan facilitation; deferrals of payments; short time work compensation and/or wage subsidies, and so on.

In Cambodia, the initial phase of the policy priorities under the state budget support package of about 3\% of GDP in 2020, includes: Supporting tourism, clothing and footwear, namely, tax breaks and exemption from contributions to social security funds; Unemployment benefits for laid-off workers (60\% of salary) are included in retraining and job improvement programs as well as employment services. Promote domestic tourism by launching campaigns to organize activities and events in Siem Reap province, 
extend the validity of tickets to the Angkor Wat complex and improve international passenger routes. In their Medium-term policy priorities, Cambodia established a new SME bank (state-owned) to support small and medium enterprises, including tourism businesses with the aim of improving competitiveness and productivity, facilitating trade and business operations (World Bank [WB], 2020).

Hong Kong government provides a 100\% guarantee for SME loans up to HK\$ 2 million. $100 \%$ reduction of corporate income tax for 2019 -2020, up to a maximum of HKD 20,000; Continued operational support measures including subsidies for $75 \%$ of electricity costs (maximum HKD 5,000 per month) for four more months and free $75 \%$ of water and wastewater costs for the next four months; Exemption from government fees including business registration fees, annual corporate tax returns and ground taxes for businesses in 2020-2021; Continue to provide rental subsidies or a $50 \%$ reduction of rent for certain businesses and certain government real estate for six months; Additional support for severely affected industries such as construction (contractor subsidies), transportation (pilot subsidy scheme, corporate income tax exemption for boat rental units) and tourism (increase funding for the HK Tourism Council to HKD 700 million) (WB, 2020). Hong Kong also created the Anti-Epidemic Fund's Travel Agents Subsidy Scheme. Accordingly, each eligible travel agent may receive a one-off subsidy of HK $\$ 80,000$. $98 \%$ of all licensed travel agents in Hong Kong have registered for the payment (World Travel \& Tourism Council [WTTC], 2020).

In Malaysia, new financing facilities for SMEs have been set up by banks in addition to a decrease in the policy rate. Dealing with negative impacts on the tourism industry,
Malaysia government prepares to pay 600 ringgit (US \$144) for each taxi driver, tourist bus driver, tour guide and registered cyclo driver (Organisation for Economic CoOperation and Development [OECD], 2020). To minimize the impact, the Government will take a three-pronged approach: first, to loosen the monetary policy to ease the cash flow for affected businesses; second, assist the affected individuals; Thirdly, stimulate the demand for travel and tourism. To reduce cash flow pressures, the Government supports the most impacted businesses for a period of 6 months starting from April to September 2020, including: (1) It is allowed to extend the time of monthly income tax payment for businesses operating in the tourism sector. In addition, companies affected by COVID-19 are also allowed to adjust their profit estimates for 2020 for monthly income tax payments without penalty; (2) Discount $15 \%$ of monthly electricity bill for hotels, travel agents, airline, shopping center, convention and exhibition center; (3) Exemption from contributions to the Human Resource Development Fund (HRDF) for tourism-related hotels and businesses; and (4) 6\% service tax exemption for hotels, starting from March to August 2020 (WB, 2020).

In the Philippines, the Travel \& Tourism sector will receive a significant portion of the government's \$523 million (PHP27.1-billion). Specifically, \$271 million (PHP14-billion) aid from the Tourism Infrastructure and Enterprise Zone Authority (TIEZA) has been earmarked for various programmes and projects of the Department of Tourism. To support workers, \$23 million (PHP 1.2 billion) from the Social Security System will be used as unemployment benefits for workers from the private sector. To promote the Philippines as a destination once in the recovery phase, the Department of Tourism (DOT) is allocating approximately 
\$118 million (PHP6 billion). At least PHP421 million earmarked for a new campaign for domestic travel and PHP467 million to create content that targets emerging countries unaffected by Covid-19 (WTTC, 2020).

Singapore government is waiving license fees for hotels, travel agents and tour guides, enhanced training schemes and subsidising them up to $90 \%$; providing salary support through Workforce Singapore of up to $70 \%$ of fixed monthly salaries (capped at $\$ 2000$ a month per employee). The government has also created a temporary bridging loan programme for cash flow support, has implemented rebates on aircraft landing and parking charges as well as rental rebates for shops and cargo agents at Changi. It has created a point-to-point support package for taxis and private hire car drivers. To further support jobs, it has created a job support scheme with a one-off wage support to help enterprises retain their workers. To further enable cash flow, it enhanced its Enterprise Financing Scheme-SME Working Capital Loan as well as implementing a corporate income tax rebate for YA2020 of $25 \%$ of tax payable, capped at $\$ 15,000$ per company (WTTC, 2020).

In Thailand, the central bank announced a reduction of the policy rate by 0.25 percentage points. On 10 March, the Government announced measures specifically targeted at SMEs, including: low-interest loans (2\% subject to a cap); rules governing the granting of commercial bank loans were relaxed by the Bank of Thailand; a reduction of withholding tax by 1.5 percentage points (from 3\% to $1.5 \%)$; tax deductions of salary expenses; Dissemination of VAT refunds in under 15 days to entrepreneurs; refunding the deposit for electricity usage; a rebate on contributions to the Social Security Fund by employers and employees, and; a planned reduction of rental fees for state property. The Finance Ministry also set up specific hotlines for SMEs with queries about these measures (OECD, 2020).

Vietnam suspended on visa issuing for foreigners entering Vietnam for a period of 30 days starting from 00:00 18 March 2020 (Government Office, 2020a); from 0:00 on 22 March 2020, halt entry to all foreigners entering Vietnam (Government Office, 2020b); agree to mobilize hotels, resorts, and tourist accommodation establishments serving as isolation facilities (Government Office, 2020c); mandate social distancing throughout the country for 15 days, from April 1 through April 15 (Prime Minister, 2020); reduce electricity price for tourist accommodation establishments as it is applicable for production households; reduce $100 \%$ of the electricity bill for the tourist accommodation establishments where they perform like isolation, medical examination and treatment facilities to serve patients infected with Covid-19 (Ministry of Industry and Trade of the Socialist Republic of Vietnam, 2020).

\section{Research questions and methodologies}

Those issues raise key questions: What are the policy measures for tourism destination management organizations to recover after Covid-19; what are the effects of social distancing in relation to globalization and global value chain on tourism development in the new context; what should be done to minimize possible discrimination of Asian tourists after Covid-19 time?, among others. As urgent measures are required to deal with the outbreak of global pandemic, research questions are raised: What are the policy measures for tourism destination management organizations to recover South East Asia's (SEA) destinations in general and Vietnam in particular after Covid-19 
in relation to globalization and global value chain, we use desk study method to collect, analyze, and synthesize secondary data. As international development organizations which are ASEAN, OECD, UNWTO, WB, WEF (World Economic Forum), WHO, and WTTC produced updated research material, we collected and synthesized countries' measures.

In terms of tourism management, we use data analysis, compare with what Vietnam has done so far and what the gaps that need to be filled are. Therefore, we present policy measures for Vietnam tourism to deal with the crisis post-pandemic of Covid-19.

\section{Discussion}

\subsection{Recovering outlook from crisis}

In April, against a backdrop of travel restrictions being introduced, UNWTO underscores the importance of international dialogue and cooperation and emphasizes the COVID-19 challenge also represents an opportunity to show how solidarity can go beyond borders. The tourism sector, like no other economic activity with social impact, is based on interaction amongst people. UNWTO stands ready to support recovery measures of its members, affirming that tourism has proved a recovery possibility (UNWTO, 2020b).

One possible policy to facilitate postcrisis tourism recovery is to subsidize tourism consumption. Such practices, like providing tourism consumption vouchers for residents, have been proved useful in China after the global financial crisis. From a general equilibrium perspective, tourism sector subsidies must be financed by resources redistributed from other sectors; A comprehensive includes simultaneous subsidies to the tourism and health sector as well. The comprehensive policy improves tourism consumption and health rebuilding, albeit at the cost of regular consumption (Yang et al., 2020).

In 2003, the Canadian Tourism Commission conducted market research in all their core markets to determine a profile of consumers who would consider travelling to Canada and those who would not. This helped to re-profile its marketing investment towards source markets, largely in Europe - those are intrepid travelers who see travel as an adventure and inherently risky (Davitt, 2020).

It is not obvious that running the risk of coronavirus outbreaks every few years - or worse - is a price worth paying for multiple annual vacation trips to Paris and Bangkok, say. The lesson from Wuhan should be that we need a broad discussion within and outside of academia about how much mobility is actually desirable. (Baldwin \& Mauro, 2020). Travelrelated illness may give rise to public health concerns that precipitate a disastrous fall in tourist revenue. The impact of globalization on infectious diseases described requires appropriate forms of global governance on improving systems for prevention, control and treatment (Saker, Lee, Cannito, Gilmore \& Campbell-Lendrum, 2020).

In America, $75 \%$ of those surveyed said their planned travel in six months will be changed due to concerns of coronavirus, $48 \%$ cancelled their trip completely, 39\% reduced travel plans, $18 \%$ changed destinations to one that they can drive to as opposed to fly, $14 \%$ changed trips from international to domestic (Longwoods International, 2020). Social distancing would be a trend for tomorrow for many sectors, including travel and tourism. One can argue that a solution for social distancing time is developing smart tourism. Nevertheless, the issue is that the rate of Internet 
use varies between $81 \%$ of the population in Singapore and $22 \%$ in Lao PDR. Therefore, policy strategies will need to be adapted to local needs. Continued regional co-operation is also needed in addressing shared and crossborder challenges in the digital economy (OECD, 2018). Most importantly, ASEAN and East Asian countries are recommended to (i) increase the supply of public goods to improve connectivity infrastructure in both physical world and cyberspace, (ii) establish rules and regulations to ensure dynamics and competition of online marketplace, (iii) improve connectivity-derived services to generate more value added, (iv) prioritise smartphone economy and Internet financial innovation, and (v) collaborate in regional rule-setting for digital connectivity (Chen, 2020).

\subsection{Recommendations by concerned development organizations}

Every government has legitimate objectives associated with infrastructure projects, education, rural and regional development programs, and the like. In the context of a more severe and complex crisis than the 2008-2009 one, it is essential to have clarity about the objectives that economic policy should pursue, and the instruments that can be deployed. If a clear understanding of the size and nature of the challenge it faced, a coherent response will be in place. UNDP's experts recommend the responses to meet three objectives: (1) minimize the human cost of the pandemic; (2) minimize the regressive effects of the crisis, with measures to protect workers' incomes, especially low-income ones; and, (3) preserve macroeconomic stability and the capacity to resume growth once the economic crisis resulting from the pandemic concludes (Levy, 2020).
According to WB's experts, it is necessary to develop a strategy in response to Covid19's crisis. The sequential approach can be divided into three steps. The first is to support the hardest-hit industries by combining tax breaks or extending the tax payment period, credit support and social security measures. The second step is to implement a number of measures stimulus, especially through accelerating the implementation of the public investment program. Finally, the third step will focus on restructuring to reduce vulnerability to similar shocks in the next few decades (WB, 2020). So far, Vietnam is performing well as this recommendation in the first step. Vietnam is also preparing for the second step after the pandemic is over hopefully in a few months and it is encouraging to consider implementing an action plan for the third step.

World Economic Forum (WEF) has launched the COVID Action Platform to catalyse private-sector support for the global public health response to Covid-19, and to do so at the scale and speed required to protect lives and livelihoods, aiming to find ways to help end the global emergency as soon as possible. The COVID Action Platform will focus on three priorities: (1) Galvanize the global business community for collective action; (2) Protect people's livelihoods and facilitate business continuity; (3) Mobilize cooperation and business support for the COVID-19 response (WEF, 2020).

WTTC urges governments to implement policies that will directly support the sector across the following three areas, namely: (1) Protecting the livelihoods of workers; (2) Fiscal support; (3) Injecting liquidity \& cash (WTTC, 2020).

ASEAN needs a general policy framework for ASEAN GVCs in tourism which contains five basic elements: embedding GVCs in 
tourism development strategies and policies; In its strategic direction, ASEAN commits to "upgrade local communities and publicprivate sector participation in the tourism value chain" (Fujita, 2018). ASEAN Tourism Strategic Plan 2016-2025 proposes to increase the number of community-based tourism projects (ASEAN, 2015).

\subsection{Measures taken in Vietnam}

To cope with the pandemic situation, the tourism industry cooperates closely with the relevant sectors to implement a number of policy solutions. In mid-February 2020, Vietnam Tourism Association launched a campaign on "Vietnam Tourism Stimulation Alliance". The Prime Minister issued Directive No.11/CT-TTg dated 4 March 2020 on urgent tasks and solutions to overcome difficulties. Next, on 24 March, MCST requested the Ministry of Finance to consider regulations on exemption and reduction of fees for supporting travel businesses and tour guides within 1 year from 1/4/2020 to promptly support those affected by Covid- 19 . When the disease situation broke out, the Prime Minister issued Directive No.16/CTTTg dated 31 March 2020 on implementation of social distancing from 1 April 2020 for 15 days; In order to promote domestic tourism market while Vietnam has not yet opened the international market, the MCST launched "Vietnamese people travel in Vietnam" program from June to December 2020. In addition to policy solutions, many businesses took their best effort to take measures to cope with financial and market crises, and take their corporate social responsibilities. Tourist accommodation establishments in Vietnam conduct a procedure of checking temperature for guests at the front desk and register for those whose body temperature is not over $37^{\circ} \mathrm{C}$. Many tourist accommodation establishments engage in provision of paid and free isolation places.

\section{Proposal of policy measures for Vietnam tourism}

5.1. Group of urgent solutions to support businesses to minimize economic losses in order to best promote the tourism business models in pandemic situations

- Consider applying the deferment of taxes and social security contributions to affected tourism businesses under the flat tax regime. In March, Vietnam applied supportive measures for businesses in all sectors such as rescheduling bank due dates, interest rate exemptions, remaining the debt, reducing fees...

- Reduce payment of credit or reduce temporary costs of credit to tourism businesses.

- Proactive employment support, provision of social insurance to stabilize employment, and social assistance transfers for tourism employees who suffer from employment disruption. Applicable tools include direct cash assistance to affected people and increased benefits of existing social assistance programs through: i) exemption or deferment of contributions social insurance (including unemployment insurance program) over a period of time; ii) loosen the conditions for unemployment insurance benefits and / or simplify the process of claiming benefits for those affected or lost their jobs; iii) use unemployment insurance fund to pay salaries and employment allowances for businesses to stabilize 
jobs, focusing on small and medium enterprises; and iv) use unemployment insurance funds to provide public employment and online training and learning services (WB, 2020).

- Develop mechanisms and strategies for crisis management in Vietnam

- Develop responsible tourism to ensure environmental sustainability

- $\quad$ Restore market confidence

\subsection{Solutions on promoting tourism stimulus} programs and public-private partnerships

- Invest in improving market intelligence and digital transformation

- Promote coordination between travel agencies and airline carriers for more flexible policymaking regarding flight bookings, including flexible policies in postponing, canceling and changing dates;

- Improve infrastructure, services and environmental situation in destinations that stimulate high demands, diversified tourism products and connectivity.

\subsection{Solutions on tourism businesses restructuring and proper business management models for a new normal situation, in line with Sustainable Development Goals in long term}

- Undertake data analysis on restructuring tourism businesses.

- Analyze strengths and weaknesses of businesses' strategies on responding to crisis caused by pandemic.

- Carry out research on target and potential markets in a new normal situation when the global value chain is shifted.

- Integrate sustainable tourism into the national development program
- Make transition to a circular or non-emission economy in line with sustainable development goals (SDGs)

\section{Conclusion}

Facing the complicated situation of Covid-19, the Government is considering actions of some countries in the region and the world to adopt proper policy measures for Vietnam to minimize economic costs stemming from the current health crisis. This paper proposes policy measures based on a three-step approach: (i) support tourism businesses in the short-term by incorporating supportive measures. tax, financial and social support; (ii) implement tourism demand stimulus measures, especially through accelerating the implementation of the public investment program to compensate for the reduction in aggregate tourism demand in the medium term; and (iii) accelerate restructural process in terms of global value chain, promote the development of a digital tourism.

\section{References}

\section{Vietnamese}

Bộ Công Thương Việt Nam. (2020). Mức hỗ trợ giá điện cho người dân và doanh nghiệp 03 tháng (tháng 4 , tháng 5 và tháng 6 ). Truy cập lúc $8: 10$ ngày $30-$ 3-2020 tại https://moit.gov.vn/web/guest/tin-chitiet/-/chi-tiet/muc-ho-tro-gia-đien-cho-nguoi-danva-doanh-nghiep-03-thang-thang-4-thang-5-vathang-6--18394-22.html

Thủ tướng Chính phủ (2020). Chỉ thị số 16/CT-TTg ngày 31-3-2020 về thực hiện các biện pháp cấp bách phòng, chống dịch COVID-19. Hà Nội.

Văn phòng Chính phủ. (2020a). Thông báo số 102/TBVPCP ngày 17-3-2020 về kết luận cuả Thủ tướng Chính phủ Nguyễn Xuân Phúc tại cuộc họp thuờng trưc Chính phủ về phòng, chống dịch COVID-19. Hà Nội.

Văn phòng Chính phủ. (2020b). Thông báo số 118/TBVPCP ngày 21-3-2020 về kết luận cuả Thủ tướng Chính phủ Nguyễn Xuân Phúc tại cuộc họp thường trụcc Chính phủ vể phòng, chống dịch COVID-19. Hà Nội.

Văn phòng Chính phủ. (2020c). Thông báo số 122/TBVPCP ngày 24-3-2020 về kết luận cuả Thủ tướng Chính phủ Nguyễn Xuân Phúc tại cuộc họp thuờng trụcc Chính phủ về phòng, chống dịch COVID-19. Hà Nội. 


\section{English}

Association of Southeast Asian Nations. (2015). ASEAN Tourism Strategic Plan 2016-2025. Manila: The Philippines Department of Tourism.

Baldwin, R., \& Mauro, B. W. D. (Eds.). (2020). Economics in the Time of COVID-19. London: Centre for Economic Policy Research Press.

Bell, D. M. (2004). Public health interventions and SARS spread, 2003. Emerging Infectious Diseases, 10(11), 1900-1906. https://doi.org/10.3201/eid1011.040729

Benjamin, W. J. (2007). Working together to grow libraries in developing countries. Cardiovascular Imaging, 27(7), 135-143. https://doi.org/10.1016/ B978-1-4160-5009-4.50004-2

Chen, L. (2020). Improving Digital Connectivity For E-commerce : A Policy Framework and Empirical Note for ASEAN. In Economic Research Institute for ASEAN and East Asia Discussion Paper Series (No. 327). Retrieved from https://www.eria.org/ publications/improving-digital-connectivity-for-ecommerce-a-policy-framework-and-empirical-notefor-asean/

Davitt, D. (2020). Coronavirus: The travel and torism impact in Asia Pacific. Retrieved from https://www. moodiedavittreport.com/coronavirus-the-traveland-tourism-impact-in-asia-pacific/. Accessed 1-42020 9:35.

Fujita, M. (2018). Global Value Chains in ASEAN: Tourism. Tokyo: ASEAN Promotion Centre on Trade, Investment and Tourism.

International Association of Scientific Experts in Tourism (2020). The response of governments vis-à-vis the economic ramifications of SARS$\mathrm{CoV}-2$. Retrieved from https://www.aiest.org/ fileadmin/memberplatform/invoices/user_upload/ Report_20200403_Government_Response.pdf

Levy, S. (2020). Suggestions for the Emergency. New York, NY: United Nations Development Programme.

Longwoods International. (2020). COVID-19 Travel Sentiment Study Wave 2. Retrieved from https:// longwoods-intl.com/news-press-release/covid-19travel-sentiment-study-wave-2

Organisation for Economic Co-Operation and Development. (2018). Economic Outlook for Southeast Asia, China and India 2018: Fostering Growth Through Digitalisation. OECD Publishing.

Organisation for Economic Co-Operation and
Development. (2020). Covid-19: SME Policy Responses. Retrieved from https://www.oecd.org/ coronavirus/policy-responses/coronavirus-covid19-sme-policy-responses-04440101/\#sectiond1e18435.

Saker, L., Lee, K., Cannito, B., Gilmore, A., \& Campbell-Lendrum, D. (2020). Globalization and infectious diseases: A review of the linkages. UNDP/ World Bank/WHO Special Programme for Research and Training in Tropical Diseases.

Wilder-Smith, A. (2006). The severe acute respiratory syndrome: Impact on travel and tourism. Travel Medicine and Infectious Disease, 4(2), 53-60. https://doi.org/10.1016/j.tmaid.2005.04.004

World Bank. (2020). Vietnam: Potential policies responses to the COVID-19 epidemic. Retrieved from https://documents.worldbank. org/en/publication/documents-reports/ documentdetail/909891589880444702/vietnampotential-policies-responses-to-the-covid-19epidemic.

World Economic Forum. (2020). Covid Action Platform. Retrieved from https://www.weforum.org/ platforms/covid-action-platform

World Health Organization. (2020). Coronavirus disease (COVID-19) outbreak situation. Retrieved from https:/www.who.int/emergencies/diseases/novelcoronavirus-2019

World Tourism Organization. (2020a). International Tourist Arrivals Could Fall by $20-30 \%$ in 2020 . Retrieved from https:/www.unwto.org/news/ international-tourism-arrivals-could-fall-in-2020

World Tourism Organization. (2020b). Tourism and COVID-19. Retrieved from https://webunwto. s3.eu-west-1.amazonaws.com/s3fs-public/2020-04/ COVID19_NewDS_.pdf

World Travel \& Tourism Council. (2020). Covid-19 Related Policy Shifts Supportive of Travel \& Tourism Sector. Retrieved from https://www.wttc. org/government-advice

Yang, Y., Zhang, H., \& Chen, X. (2020). Coronavirus pandemic and tourism: Dynamic stochastic general equilibrium modeling of infectious disease outbreak. Annals of Tourism Research, 83, 102-114. https:// doi.org/10.1016/j.annals.2020.102913 


\title{
GIẢI PHÁP CHÍNH SÁCH CHO DU LỊCH VIỆT NAM ÚNG PHÓ VỚI DỊCH COVID-19
}

\author{
Vũ Chiến Thắng \\ Phòng Quản lý Khoa học và Hợp tác quốc tế, Viện Nghiên cứu Phát triển du lịch \\ 58 Kim Mã, Ba Đình, Hà Nội, Việt Nam
}

Tóm tắt: Trong bối cảnh toàn cầu đang thực hiện các giải pháp cấp bách nhằm tháo gỡ khó khăn cho sản xuất kinh doanh, bảo đảm an sinh xã hội ứng phó với dịch Covid-19, ngành du lịch Việt Nam cũng cần phải xây dựng các giải pháp chính sách giảm thiểu thiệt hại kinh tế. Dựa vào các tài liệu nghiên cứu của các tổ chức phát triển quốc tế về xây dựng các giải pháp chính sách cho kinh tế - xã hội và nghiên cứu các điển hình ở các quốc gia châu Á từ khi đại dịch bùng phát trên khu vực và thế giới, chúng tôi đề xuất các giải pháp về chính sách cho du lịch Việt Nam. Bên cạnh thực trạng ảnh hưởng nặng nề do dịch Covid-19, các biện pháp chính sách quản lý trong bài nghiên cứu này gồm 3 nhóm: (1) hỗ trợ doanh nghiệp giảm thiểu thiệt hại kinh tế nhằm phát huy tốt nhất mô hình kinh doanh du lịch trong điều kiện dịch bệnh ; (2) thúc đẩy các chương trình kích cầu du lịch, phát huy tốt mối quan hệ đối tác công - tư ; (3) cơ cấu lại hệ thống doanh nghiệp du lịch và mô hình quản lý kinh doanh du lịch phù hợp với tình hình mới, đảm bảo đạt được các mục tiêu phát triển bền vững của Liên hợp quốc trong dài hạn.

Tù khóa: giải pháp chính sách, du lịch Việt Nam, Covid-19 